\title{
Historical deadly typhoons in the Philippines
}

\section{Pedro Ribera, ${ }^{1}$ Ricardo García-Herrera ${ }^{2}$ and Luis Gimeno ${ }^{3}$ Spain
${ }^{3}$ Universidad de Vigo, Spain \\ 1 Universidad Pablo de Olavide, Sevilla, \\ 2 Universidad Complutense de Madrid,
Spain}

Tropical cyclones (TC) are among the most destructive natural hazards in the world. Native populations in the TC-prone areas use different words to name them. In the Caribbean region they are traditionally known as hurricanes, a Caribbean word adopted by the Spanish and then translated into the other western languages, while in the western North Pacific area, the terms baguio, in the Philippines, and typhoon, in China and Japan, are used. The physical mechanisms responsible for their development are complex and not fully understood, but it is known that they require high sea-surface temperatures (SST), a moderate Coriolis force, a preexistent synoptic perturbation (normally a monsoon trough or easterly wave) and low wind shear (Fink and Speth, 1998; Galvin, 2008). The dependence on high sea temperature has opened the debate on a possible increase in the frequency of tropical cyclones in a changing climate. It has been proposed that a rise in SST induced by the anthropogenic global warming has already led to a greater number of intense tropical cyclones in recent decades (Emanuel, 2005; Webster et al., 2005). Whether this trend is real or an artefact of the short length and inhomogeneity of records is a matter of keen scientific argument (Holland and Webster, 2007). Irrespective of such considerations, the increase of population and valuable properties in the areas affected by TCs, makes it very likely that their impact should increase in the near future. In this context, the reconstruction of past TC behaviour can throw some light on this debate.

Reconstructions based on sedimentary records have produced valuable TC series detectable signal. Lakes near the ocean, where marine sediments are accumulated only when an intense TC hits the area, provide reliable data about past activity. In this way, centennial to millennial TC variability can be examined. In Puerto Rico, these studies have helped to identify active periods for intense hurricanes in the late eighteenth century, between 2500 and 1000 years before present (BP, before present defined as $1950 \mathrm{AD}$ by convention) and between 5400 and 3600 years BP (Donnelly and Woodruff, 2007). Sediment cores from different lakes helped to identify active TC periods over the last 7000 years along the US Gulf Coast (Liu and Fearn, 2000).

Sedimentary cores produce low resolution series that permit the analysis of centennial to millennial variability but they are not able to identify annual to multidecadal variability. Thus, other sources must be used to produce temporal high-resolution series. Among them, historical archives have proven useful to produce annually resolved series over different TC-prone areas. As an example, 500-year-long hurricane occurrence series over the Caribbean area have been reconstructed using records extracted from colonial archives, kept both in Europe and in America (Millás 1968; García-Herrera et al., 2005, 2007a; Chenoweth, 2006). TC chronologies from historical records over other TC-prone areas are not so detailed. Two main sources have been used to build typhoon chronologies in the western North Pacific sector. Some continental areas have detailed records of past typhoon incidences. As an example, Liu et al. (2001) used old Chinese records to build a chronology of typhoons strikes on the coasts of Guangdong (Southern China) over the last 1000 years. But typhoons over oceanic sectors are not so well documented although historical archives have been used to extend typhoon chronologies over the Philippines and part of the northwestern Pacific basin (NWP). See Ribera etal. (2005) and García-Herrera et al. (2007b) for details on this series, compiled by the Jesuit Miguel Selga in the mid1930s. The aim of this article, however, is to identify further deadly typhoons occurring in the Philippines as derived from Selga's chronology.

\section{Historical context and data source}

During most of the colonial times (15501898) the Philippines did not produce a significant volume of spices or any other valuable crop, instead they acted as an intermediate port between Chinese merchants and the Nueva España (currently Mexico) territory. In other words, they were a logistics platform between Asia and America, and, consequently, highly dependent on maritime trade. Every spring the Chinese ships sailed from Guangdong to Manila moved by the monsoon winds; they carried highly valuable goods such as silks, porcelain, pottery, carpets or jewels from countries along the western Pacific Ocean, India and even Iran. This merchandise was sold to Manila merchants and agents who organized one or two ships (the Manila Galleon) with sizes ranging between 500 and 900 tons, that usually sailed for Acapulco in July. There, a market fair was held, with traders from Nueva España and Peru, and the cargo was sold and paid for in silver. On the return trip, the ships transported the passengers (usually priests and soldiers) and silver, including the annual Crown subsidy to the Colony that was used to pay the royal officers and the island's garrison. The Galleon was the main economic activity of the islands and it had a tremendous impact, not only in the Philippines, but also in Nueva España. In fact, the value of the Acapulco fair was so big that it raised continuous claims from the merchants of mainland Spain, who saw their business threatened by the Galleon's system, since it transported too much silver back to Manila and China. This ensured that only one or two ships were allowed every year by the Crown. This commercial route worked for 250 years. It started in 1565 when the founder of Manila, Miguel López de Legazpi, following the advice of Andrés de Urdaneta, an Augustan friar with previous sailing experience, succeeded in crossing the Pacific eastward for the first time in almost 15 years of Spanish settlement in the Philippines. From that point, the town grew rapidly and its layout in 1671 is shown in Figure 1. The route to Acapulco (Tornavuelta) spanned around $2500 \mathrm{~km}$ and was followed until the last galleon arrived in Acapulco in 


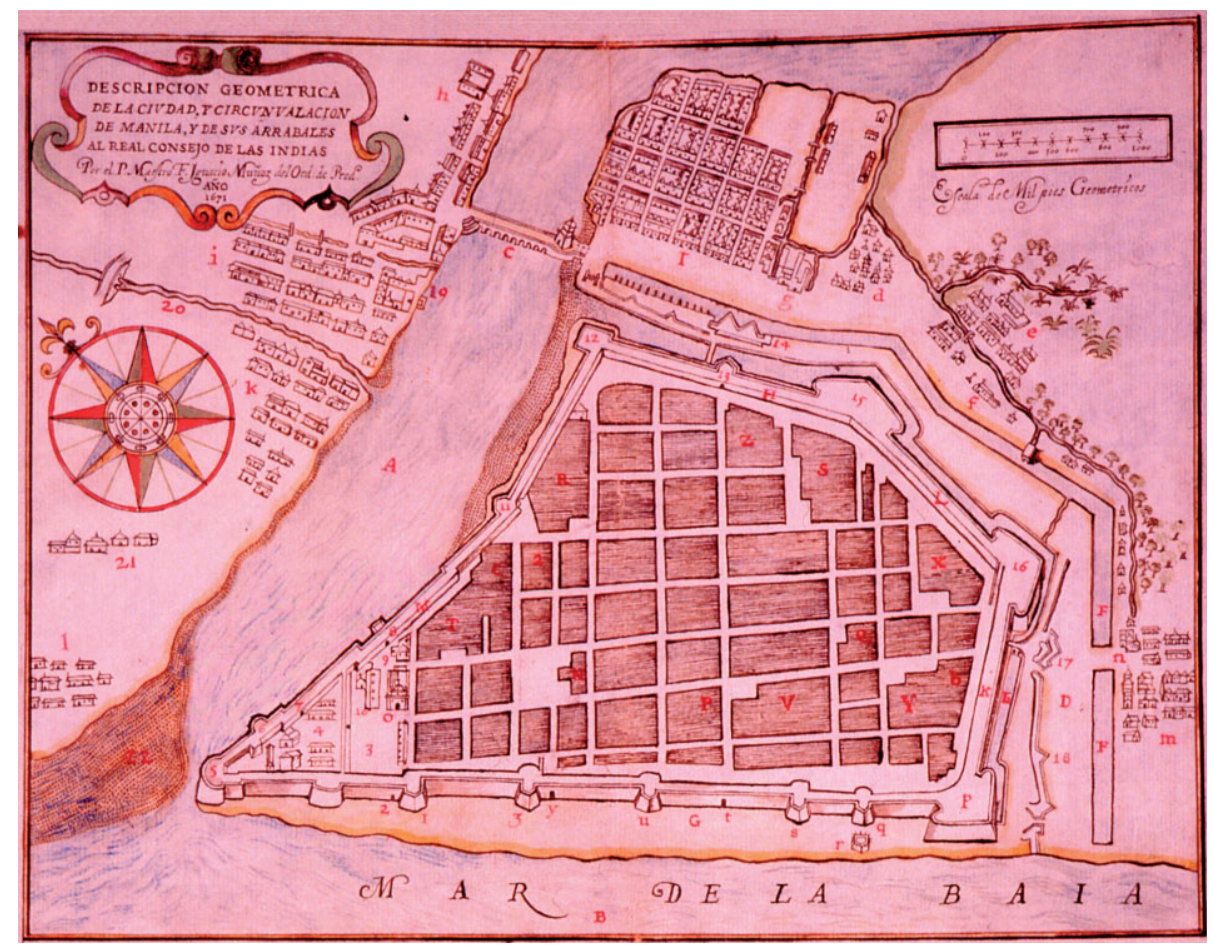

Figure 1. Layout of the city of Manila as it appeared in 1671. By kind permission of the Ministerio de Cultura, Archivo General de Indias (Seville), AGl, MP-Filipinas, 10, Cartas y Expedientes de Gobernadores de Filipinas, 1670-1677.
1815, a few years before Mexico became independent. For details about the Manila Galleon see Schurtz (1939).

During the route, the speed of the ship was less important than the safety of the extremely valuable cargo. The main threat was the weather, since, in this period, the Pacific was very scarcely sailed by pirates or ships from other nations. Thus, the English, even when they tried to capture the ship, only succeeded four times: Cavendish in 1587, Rogers in 1709, Anson on 1743 and Cornish 1762; the Dutch, attacked the Galleon frequently, but were not able to capture it (Schurtz, 1939). Typhoons and heavy weather were a more serious risk, thus, 14 ship losses or heavy damages have been reported for the period 1590-1750 associated with heavy weather (García et al., 2001). In fact, the timing of the route was a compromise to avoid the peak of the typhoon season when leaving Manila and to find favourable conditions when approaching Manila from Acapulco (García et al., 2001). A letter to the Spanish king, written by an unknown Crown officer after 1656 illustrates this point (Archivo General de Indias, Filipinas, 935):

... H.M. (His Majesty) has also ordered that the ships not wait until April [to sail from Acapulco], this time was formerly held to be safe, but because of changes in the monsoons and the great lengthening of the voyages it seems appropriate that navigation should commence earlier.... It is considered that a good voyage from the Philippines to Acapulco is one that does not exceed seven months, so, in order to be able to return in time, they should not wait until an example of an early map of the region (from 1571) is seen in Figure 2. The Jesuits arrived in the Philippines in the sixteenth century and played an active role both as missionaries and as natural scientists. In fact they founded the Manila Observatory and its associated network of meteorological stations in the second half of the nineteenth century and managed it until it became part of the Philippines National Weather Service after World War II (Udias, 2003; Ribera et al., 2005). Miguel Selga was a Spanish Jesuit who became the last Spanish director of the Manila Observatory, between 1926 and 1946. In 1935 he published his Catalogue of typhoons 1348-1934, which he describes as '... an abridged enumeration of the storms and typhoons as described by old chroniclers or described by contemporary documents'. See Ribera et al. (2005) and García-Herrera et al. (2007b) for details of Selga's chronology.

\section{Deadly typhoons}

Selga's chronology contains a total of 524 reports about typhoons before the twentieth century. From them, we have extracted those records which contain explicit references to deaths associated to the typhoons occurrence. They have been classified according to three types: records with an estimation of casualties in the Philippines (Table 1), records where death occurrence is reported, but the number of casualties is not provided (Table 2) and records with estimation of deaths in the Philippines and the Asian continent (Table 3). The islands and locations referenced in the tables are shown in Figure 3.

The deadliest typhoon affecting the Philippines included in Selga's chronology

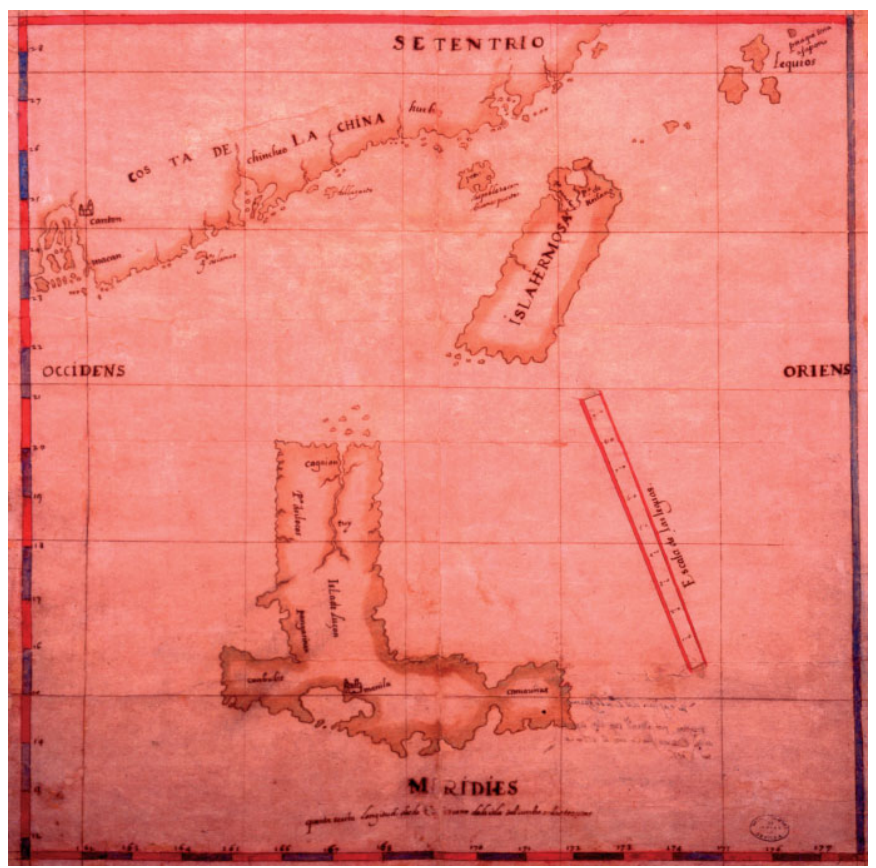

Figure 2. An example of an early map of the islands of Luzon, Hermosa and part of the China coast from the year 1597. By kind permission of the Ministerio de Cultura, Archivo General de Indias (Seville), AGl, MP-Filipinas, 6, Cartas y Expedientes de Gobernadores de Filipinas, 1565-1601. knowledge of such risks and of the geography of these waters was important and

July to leave [Manila], but should move up in the year 1656, I departed at the end of All this suggests that the Spanish were aware of typhoons since the very beginning of their settlement in the Philippines. A 
Deadly typhoons in the Philippines according to Selga's chronology. For every typhoon the date, number of deaths, impact as described by Selga and affected location are provided.

\begin{tabular}{|c|c|c|c|}
\hline Date & Deaths & Description & Location \\
\hline 1867 / 9 / 20 & 1800 & $\begin{array}{l}\text { Inundation and destruction + shipwreck (victims not } \\
\text { included in the } 1800 \text { deaths) }\end{array}$ & Luzon \\
\hline $1897 / 10 / 7$ & 1500 & Destruction and tsunami & Samar, Leyte and Mindoro \\
\hline $1617 / 10 / 10$ & 1000 & Shipwreck & Marinduque \\
\hline $1639 / 8 / 5$ & 750 & Shipwreck & Luzon \\
\hline $1767 / 10 / 23$ & 500 & Inundation and destruction & Luzon \\
\hline 1694 / 7 / 3 & 400 & Shipwreck & Luban \\
\hline $1649 / 10 / 5$ & 200 & Shipwreck & Luzon and Samar \\
\hline $1831 / 10 / 22$ & 150 & Inundation and destruction & Luzon \\
\hline $1876 / 11 / 25$ & 150 & Destruction & $\begin{array}{l}\text { Mindanao, Visayas, Bohol, Cebu, Panay, } \\
\text { Negros and Calamianes }\end{array}$ \\
\hline $1863 / 12 / 13$ & 49 & Destruction & Luzon and Camarines \\
\hline 1757 / 12 / 29 & 36 & Shipwreck & Visayas and Mindanao \\
\hline $1844 / 11 / 13$ & 32 & Destruction & Luzon and Camarines \\
\hline $1900 / 11 / 13$ & 20 & Destruction and shipwreck & Marianas \\
\hline $1845 / 10 / 7$ & 12 & Destruction & Luzon \\
\hline $1871 / 3 / 25$ & 11 & Shipwreck & Samar and Luzon \\
\hline $1866 / 4 / 28$ & 9 & Shipwreck & Luzon and Mindoro \\
\hline $1867 / 11 / 14$ & 5 & Destruction & Visayas \\
\hline $1875 / 12$ / 18 & 4 & $\begin{array}{l}\text { Destruction and shipwreck. Two reports include infor- } \\
\text { mation about this event. }\end{array}$ & Luzon \\
\hline $1793 / 8 / ?$ & 3 & Shipwreck & Panay \\
\hline $1870 / 3 / 8$ & 3 & Shipwreck & Samar \\
\hline $1870 / 5 / 5$ & 3 & Destruction & Samar, Leyte, Negros and Visayas \\
\hline $1881 / 8 / 16$ & 2 & Destruction & Luzon \\
\hline $1768 / 9 / 8$ & 1 & Typhoon hit ship & Pacific Ocean \\
\hline
\end{tabular}

\section{Table 2.}

As table 1, but for those typhoons not including an estimation of the number of deaths.

\begin{tabular}{|lll|} 
Date & Description & Location \\
\hline $1598 / 10 / 4$ & Shipwreck & China Sea \\
$1638 / 9 / 20$ & Shipwreck & Marianas \\
$1871 / 10 / 5$ & Destruction, not as bad as in 1867 & Luzon \\
$1872 / 10 / 12$ & Destruction & Luzon and Samar \\
$1874 / 11 / 9$ & Destruction and shipwreck & Samar and Leyte \\
$1875 / 1 / 1$ & Destruction and shipwreck & Samar and Zambales \\
$1875 / 10 / 24$ & Destruction and shipwreck & Visayas and Luzon \\
\hline
\end{tabular}

is the one that affected the Philippines between 20 and 26 September 1867. The report about this typhoon reads:

'From the 20th to the 26th of September, Manila experienced a violent storm which caused the inundation of all the city suburbs. The Malacañang Palace, residence of General Gandara, became isolated, and the officials had to make use of boats to reach the place, all adjacent barrios (city districts) being surrounded temporarily by a lake. This typhoon passed to the north of Manila. The force of the wind was hurricane

\section{Table 3.}

As table 1, but for those typhoons reporting an estimation of the number of deaths on the Asian continent.

\begin{tabular}{|c|c|c|c|}
\hline Date & Deaths & Description & Location \\
\hline $1780 / 7 / ?$ & 100000 & Piddington Maps & Canton and Macao \\
\hline 1862 / 7 / 27 & 40000 & Destruction & Canton and Macao \\
\hline $1881 / 9 / 27$ & 20000 & $\begin{array}{l}\text { Destruction in Philippines and the continent. } \\
\text { Deaths in the continent }\end{array}$ & Luzon and the Tong King Gulf \\
\hline $1894 / 9 / 15$ & 2000 & $\begin{array}{l}\text { Destruction in the Philippines and deaths in Macao } \\
\text { and Hong Kong }\end{array}$ & $\begin{array}{l}\text { Marianas, Luzon, Mindanao, Hainan, Hong } \\
\text { Kong and Macao }\end{array}$ \\
\hline
\end{tabular}




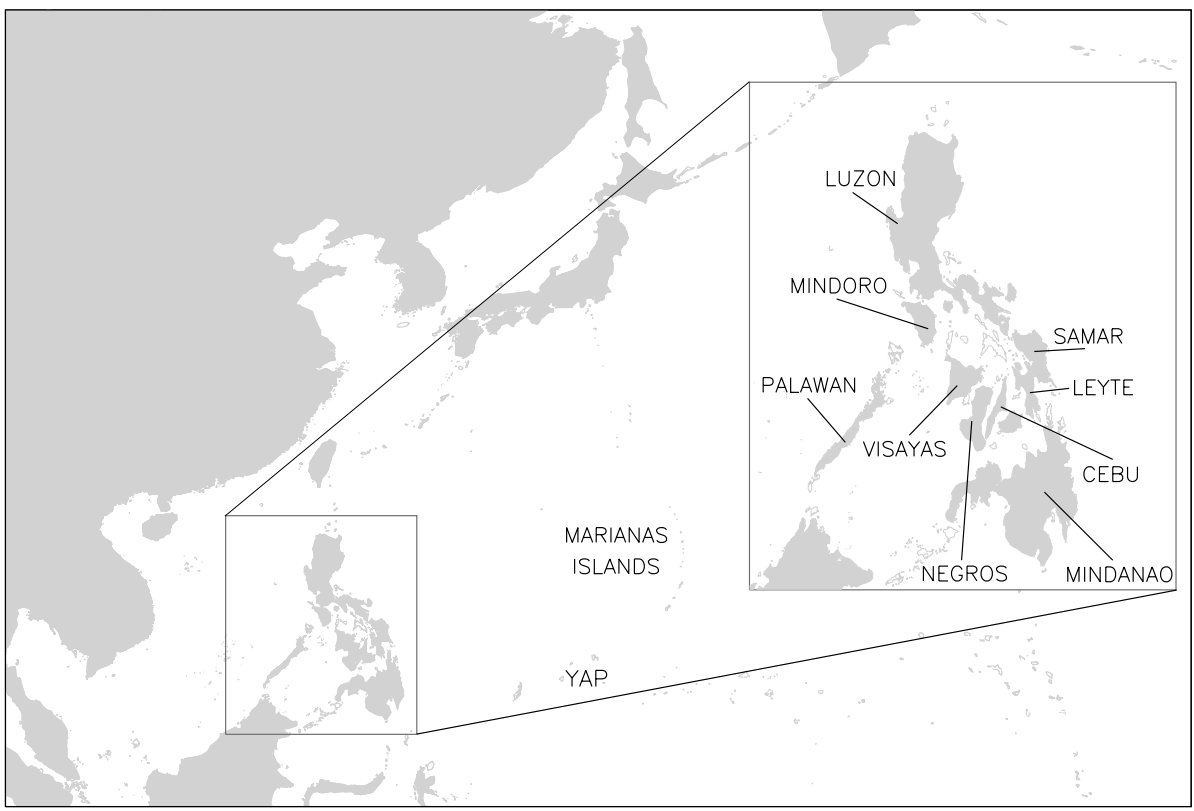

Figure 3. Western North Pacific area where typhoon activity is reported in Selga's chronology.

for 10 hours. The barometer fell in Manila to $737.30 \mathrm{~mm}$ (approx $982 \mathrm{hPa}$ ) at $6 \mathrm{am}$ on the 27th. Seventeen ships were dashed against the Santa Lucia and Tondo shores. The waves in Manila Bay were mountainous. The Ayuntamiento (city council), with the consent of Gandara, distributed P3000 to aid the sufferers of the storm. The officials and the religious corporations exerted every effort to better the conditions of the injured and of those who were unable to leave their houses during the progress of the inundation. By Royal Decree of the 21st of December, the expenditures incurred were approved and La Direccion de Administracion (Administration Management) was instructed to appropriate in the coming budget, a certain sum under the item "Public Calamities" to spend in similar cases of emergency. On the 25th of September a frightful inundation occurred in llocos, owing to the extraordinary flooding of the Abra River. The water reached a height of 25 meters above the ordinary level, killing 1800 persons and causing incalculable damages to property in llocos and in Abra. Returning from Hong Kong where it had gone to get the mail from Europe the ship Malespina was caught by the terrible storm. Undoubtedly, it got caught in the vortex of the hurricane in the China Sea, and went to the bottom. The plain fact is that nothing more has ever been heard about the ill-fated ship, not even the slightest debris has ever been seen to testify to the unexpected end of the ill-fated crew and passengers... '.

More than 1800 people died in the Philippines due to the effects of this typhoon, and this number does not include the people who died in the wreck of the Malespina. The memory of this typhoon was kept for a long period and reports on typhoons occurring after the 1867 big typhoon very often include references to this event, as will be shown below.

On 7 October 1897, the second-deadliest typhoon recorded by Selga in his chronology hit the Philippines. The information included on the typhoon is not as detailed as in the previous case, but it provides an impression of its intensity from the fact that a sea level pressure of $710 \mathrm{~mm} \mathrm{Hg}$ (approx. $946 \mathrm{hPa}$ ) was measured along the typhoon trajectory:

'Moving from $E$ of the Western Carolines in a direction near $E-W$, the typhoon crossed Samar and Leyte and then moved over $S$ Mindoro towards the China Sea. The barometric minimum at Guiuan, Samar, was of $710.0 \mathrm{~mm}$ (approx 946hPa). It caused a tremendous wave which in S Samar and $N$ Leyte destroyed completely several towns and claimed about 1500 human victims. It wrecked numerous boats within the Archipelago and put in great danger of foundering many others in the China Sea, where it inclined to NW'.

As stated in the report, the extremely large number of victims was probably caused by the development of the extreme wave that destroyed several towns on the southern coasts of Samar and northern coasts of Leyte.

The third-deadliest typhoon included in Selga's chronology occurred on 10 October 1617. It is reported in a very succinct report:

'A very severe typhoon crossed Visayas. Six ships were wrecked near Marinduque with the loss of over a thousand persons. It was considered as the greatest calamity during the administration of Jeronimo de Silva'.
As it can be seen, this report includes only information about the place where the typhoon was noted and no additional information is included about possible impacts of the typhoon on land. The deadly character of the typhoon is produced only by reference to the 6 shipwrecks that caused more than 1000 deaths.

The fourth case occurred on 5 August 1639, when:

'A very strong typhoon raged over the China Sea and the western coast of Luzon. Out of five ships that had left Manila for Acapulco, two of them foundered near Cavite with the loss of 600 Chinese. Two ships coming from Acapulco to Manila were wrecked in the coast of Vigan, with the loss of 150 persons. The material losses amounted to more than half a million pesos.'

On 23 October 1767, another catastrophic typhoon hit the Philippines, producing more than 500 victims. This time, a combination of intense rain and high tides produced the inundation of Manila and nearby towns, and it was this inundation what produced the high number of deaths. The complete report reads:

'The following typhoon was reported by the French astronomer Le Gentil who happened to be in Manila. In October 22, there was felt in Manila a typhoon which although not shifting around all points of the compass, but only from NW to SW through W, yet caused considerable damage in Manila and its neighbourhood. The districts of Manila were inundated as a result of an enormous quantity of rain and simultaneous high tides. In the town of San Mateo alone more than 500 persons perished as a result of the hurricane and the heavy floods of the San Mateo river.'

These reports, corresponding to the five typhoons with a highest number of deaths estimated for the Philippines, show that the estimation of casualties included in Selga's chronology is conservative, since, for example, in the last report 500 is the number of victims in a single town (San Mateo), but no information is provided about victims in nearby towns, nor in Manila itself. Another example is the report of the typhoon that affected Luzon on 16 October 1881; it included the death of the lighthouse keeper and his family, due to the violence of the storm, but it does not include any reference to people affected anywhere else in the island ('... The lighthouse of San Nicolas shoal, in the Bay of Manila, was destroyed with loss of the keeper and his family...').

This is reinforced when analysing the records of the typhoons included in Table 2. As an example, on 5 October 1871, a very detailed description is provided about another typhoon affecting the islands: 
'The provinces in central and northern Luzon suffered very heavily from the storm of the first fortnight of October. In Dili Bay, Mindoro, the vessel Ntra. Sra. de Guadalupe was wrecked. The inundations in Pampanga caused losses in sugar cane and the demolition of houses in many towns. The losses in public buildings, roads, private houses, crops, and property were terribly great in Pangasinan. On its coasts several vessels were lost and some persons drowned. In Lingayen, the water rose to such a height that within a short time, it reached a height of eight feet above the town. Similar mishaps occurred in Nueva Ecija. In Baler alone, the storm damaged 27 houses made of nipa and 5 of wood. In Dicapulao, the convent, church, courthouse, constabulary headquarters, and the 16 houses of the mission were all destroyed, The inundations and wind were so violent in Nueva Vizcaya, that many houses were raised to the ground, and a great number of different kinds of trees were uprooted. In Lepanto, the furious wind from the south to the east completely destroyed everything that the storm on the 29th of September had spared. The constabulary headquarters of Sabañiga fell to the ground. The damage was greatest in llocos. In the afternoon of October 4th, the strong tempest from the NNW, accompanied with an extraordinary and sudden rise of the Abra River, recalled to memory the inundation of 1867. On the 6th, the water rose almost as high as during the year aforementioned, causing equal inundation in San Vicente, Santa Catalina, Cauayan, Bantay, and Vigan. Although the inundation was not destructive as that of 1867, it, however, carried away 28 houses in Vigan, 50 houses in Cauayan, 4 houses of wood, 10 of timber, and 3 granaries of palay in Santa Catalina. ...... In llocos Norte, all the roads were destroyed. 460 houses disappeared; 1343 cattle, 842 horses, 761 carabaos, and numberless hogs and chicken were drowned. .... In the town of Dingras alone, where the baguio and rain were very violent, 490 houses and 600 seedbeds of palay were destroyed. ....... In the whole province of Cagayan, many edifices were destroyed, and the inundation caused three fourths of the crops to be damaged. In Bangued, Abra, the northwest wind blew with tremendous force for three days, with torrential rains. There was hardly any difference between this inundation and the inundation of the year 1867. The waters of the river inundated the extensive rice fields of the towns, leaving the lawn and trees submerged from 5 to 6 metres and even in some places even to 20 metres below the water. Six bridges collapsed, 64 houses were dragged down by the water, 200 heads of cattle were drowned. The lgorots (natives) of the mountains of Bontos, Sagada, Ambuyan and Alab lost their crops of sweet potatoes and corn, and the flood carried away the seedbeds which the lgorots possessed in their ditches, formed by many years of work. On the banks of the rivers, some dead bodies of drowned lgorots were found...'.

From the description included in this report, it is evident how catastrophic this event was. This report also includes a detailed inventory of destroyed houses, lost harvests, damaged infrastructures, inundated areas or drowned animals, among other things, in many regions of the Islands. Several comparisons are offered between this typhoon and the one that occurred in October 1867, and it is said that this typhoon was almost as bad as the former. It is evident also - even though this report only includes a short reference to those who drowned in Pangasinan and in the region of the lgorots and that no absolute numbers are provided - that this typhoon must have caused a greater number of victims.

Table 3 includes those reports where a number of deaths has been estimated, but associated here with the typhoon's impact on the Chinese coastline. From the transcriptions of these reports included below, it is clear that Selga here provides a rough estimate of the real number of human losses.

1780/7/?: 'The maps of Piddington show a typhoon which moved along the coast of China passing south of Canton and Macao. All the ships which were at sea that night were lost. Surely, more than 100,000 persons died in the storm. At first the wind was from ENE. At 8, the wind violently shifted to the SE. At midnight, it veered fasted to the $S$ with the same violence, and having notice that we had come into shallower water. At dawn we fathomed the sea and measured 72 feet.'

1862/7/27: 'The typhoon that hit Canton and Macao must be termed destructive. The victims were at least 40000 and the loss on property of millions of dollars. The aspect of Praia Grande after the typhoon was disheartening. The barometer fell to $726.44 \mathrm{~mm}$.'

1881/9/27: 'A typhoon appeared ESE of Manila and advanced to WNW through Camarines, Tayabas and Batangas provinces, doing much damage. In the China Sea, it gained tremendous development, wrecked some steamers and invaded Tongking with a high wave, which caused as much destruction as the fury of the wind. Twenty thousand human corpses were recovered after the storm. The barometric minimum on the steamer Fleurs Castle at about $15^{\circ} \mathrm{N}$ and $113^{\circ} \mathrm{E}$ was $717.50 \mathrm{~mm}$ (approx. $956 \mathrm{hPa}$ ).'

1894/9/15: 'A typhoon, from a point $E$ of northern Mindanao, moved in a WNW direction and entered Luzon through Nueva Ecija. In the oriental cordillera, it divided itself into two branches. One branch went $W$ to Zambales. The other went NNW to Pangasinan and La Union, after which it changed its direction to WNW and reached the Continent N of Hainan. The first branch was filling up during its movement in the China Sea, but joined the other branch before it was entirely filled up. The barometric minimum at San Isidro before dividing was $736.8 \mathrm{~mm}$ (approx $982 \mathrm{hPa}$ ). The barometric minimum of the north branch at San Fernando was $737.15 \mathrm{~mm}$ (approx. $982 \mathrm{hPa}$ ) and at Bolinao, second branch, was $740.0 \mathrm{~mm}$ (approx. $986 \mathrm{hPa}$ ). The damage was considerable.' 'After crossing $N$ Marianas, the typhoon took a WSW direction and, when half way between Marianas and Luzon, it inclined to the WNW. Then it passed through Balintang Channel and continued to the southern coast of China, near Canton. The barometric minimum at Macao was $724.4 \mathrm{~mm}$ (approx. $989 \mathrm{hPa}$ ). Much damage at Hongkong and Macao; more than 2000 victims.'

\section{Conclusion}

A total of over 6500 deaths are reported in Selga's chronology in the Philippines or other islands. But this must be a very conservative estimate of the actual impact on human lives of typhoons in the Philippines in historical times due to a number of factors. First, Selga does not pretend to have included all the typhoons over the area since the fourteenth century. In the introduction of the book he writes:

'Although the catalogue of historical typhoons represents many hours of painstaking search in libraries and reading of books in various languages, no claim is made that the catalogue is complete or altogether free from inaccuracies; additions and corrections will be welcome.'

Additionally, Selga used both primary and secondary sources to build his chronology, which may have resulted in significant differences in the type and quality of the available information, such as seen when comparing the reports of the five deadliest typhoons. Selga was primarily interested in identifying typhoon occurrence, but not in estimating their impact. This may explain the noticeable increase in the rate of typhoon reports dated after 1865 in the Selga chronology that include data about the effects of typhoons and include meteorological information only. This increasing neglect on the part of Selga is unexpected because from that year onwards a network of secondary observatories associated with the Manila observatory started providing the possibility of more reliable information on such impacts.

Such peculiarities notwithstanding, Selga's reports remain the best estimate currently available of death casualties associated with 
typhoons in the Philippines and serve as a starting point with which to build a comprehensive catalogue of deadly typhoons in the Western North Pacific basin. This exercise has been made in the Atlantic (Rappaport and Fernández-Partagás, 1997; Blake et al., 2007), but, to our knowledge, no systematic attempts have been made in the Pacific basin but, as this article has indicated, the possibility clearly exists.

\section{Acknowledgement}

We wish to thank the Archivo General de Indias (Seville) for their kind permission for the publication of two of the images included in this paper.

\section{References}

Blake E, Rappaport E, Landsea C. 2007. The deadliest, costliest and more intense United States tropical cyclones from 1851 to 2000. NOAA Technical Report NWS TPC-5 Miami 45 pp.

Chenoweth M. 2006. A reassessment of historical Atlantic basin tropical cyclone activity, 1700-1855. Climatic Change 76: 169-240.

Donnelly JP, Woodruff JD. 2007. Intense hurricane activity over the past 5000 years controlled by El Nino and the West African Monsoon. Nature 447: 465-468.

Emanuel K. 2005. Increasing destructiveness of tropical cyclones over the past 30 years. Nature 436: 686-688.

Fink AH, Speth P. 1998. Tropical cyclones. Naturwissenschaften 85: 482-493.
Galvin JF. 2008. The weather and climate of the tropics, Part 7 - Tropical revolving storms. Weather (in press).

García-Herrera R, Gimeno L, Ribera P, Hernández E. 2005. New records of Atlantic hurricanes from Spanish documentary sources. J. Geophys. Res. 110: D03109; DOI:10.1029/2004JD005272. 2005.

García-Herrera R, Gimeno L, Ribera P, Hernández E, González E, Fernández G. 2007a. Identification of Caribbean basin hurricanes from Spanish documentary sources. Climatic Change DOI: 10.1007/ s10584-006-9124-4.

García-Herrera R, Ribera P, Hernández E, Gimeno L. 2007b. Northwest Pacific typhoons documented by the Philippine Jesuits, 1566-1900. J. Geophys. Res. 112: D06108, DOI:10.1029/2006JD007370.

García RR, Díaz H, García Herrera R, Eischeid J, Prieto MR, Hernández $E$, Gimeno L, Rubio F, Bascary AM. 2001. Atmospheric circulation changes in the tropical Pacific inferred from the voyages of the Manila Galleon in the $16^{\text {th }}$ - $18^{\text {th }}$ centuries. B. Am. Meteorol. Soc. 82: 2435-2456.

\section{Holland GJ, Webster PJ. 2007.}

Heightened tropical cyclone activity in the North Atlantic: natural variability or climate trend? Philos. T. Roy. Soc. A. 365: 2695-2716.

Liu KB, Fearn ML. 2000. Reconstruction of prehistoric landfall frequencies of catastrophic hurricanes in Northwestern Florida from lake sediment records. Quaternary Res. 54: 238-245.

Liu KB, Shen CM, Louie KS. 2001. A 1000-year history of typhoon landfalls in Guangdong, Southern China, reconstructed from Chinese historical documentary records. Ann. Assoc. Am. Geogr. 91: 453-464.

Millás JC. 1968. Hurricanes of the

Caribbean and adjacent regions 1492-1800.

Academy of the Arts and Sciences of the Americas: Miami. 326 pp.

Rappaport E, Fernández-Partagás J. 1997. History of the deadliest Atlantic tropical cyclones since the discovery of the New World. In Díaz H, Pulwarty R (eds). Hurricanes: climate and socioeconomic cmpacts. Springer: Berlin. 292 pp.

Ribera P, García-Herrera R, Hernández

E, Gimeno L. 2005. Typhoons in the

Philippine Islands, 1901-1934. Climate Res. 29: 85-90.

Schurz WL. 1939. The Manila Galleon. E.P. Dutton \& Company: New York. 453 pp.

Udías A. 2003. Searching the heavens and the Earth. The history of Jesuit observatories. Kluwer Academic Publishers: Dordrecht. $369 \mathrm{pp}$.

Webster PJ, Holland GJ, Curry JA,

Chang HR. 2005. Changes in tropical cyclone number, duration, and intensity in a warming environment. Science 309: 1844-1846.

Correspondence to: Pedro Ribera, Departamento de Sistemas Físicos, Químicos y Naturales,

Universidad Pablo de Olavide, Sevilla, Spain.

\section{Email:pribrod@upo.es}

(c) Royal Meteorological Society, 2008

DOI: 10.1002/wea.275

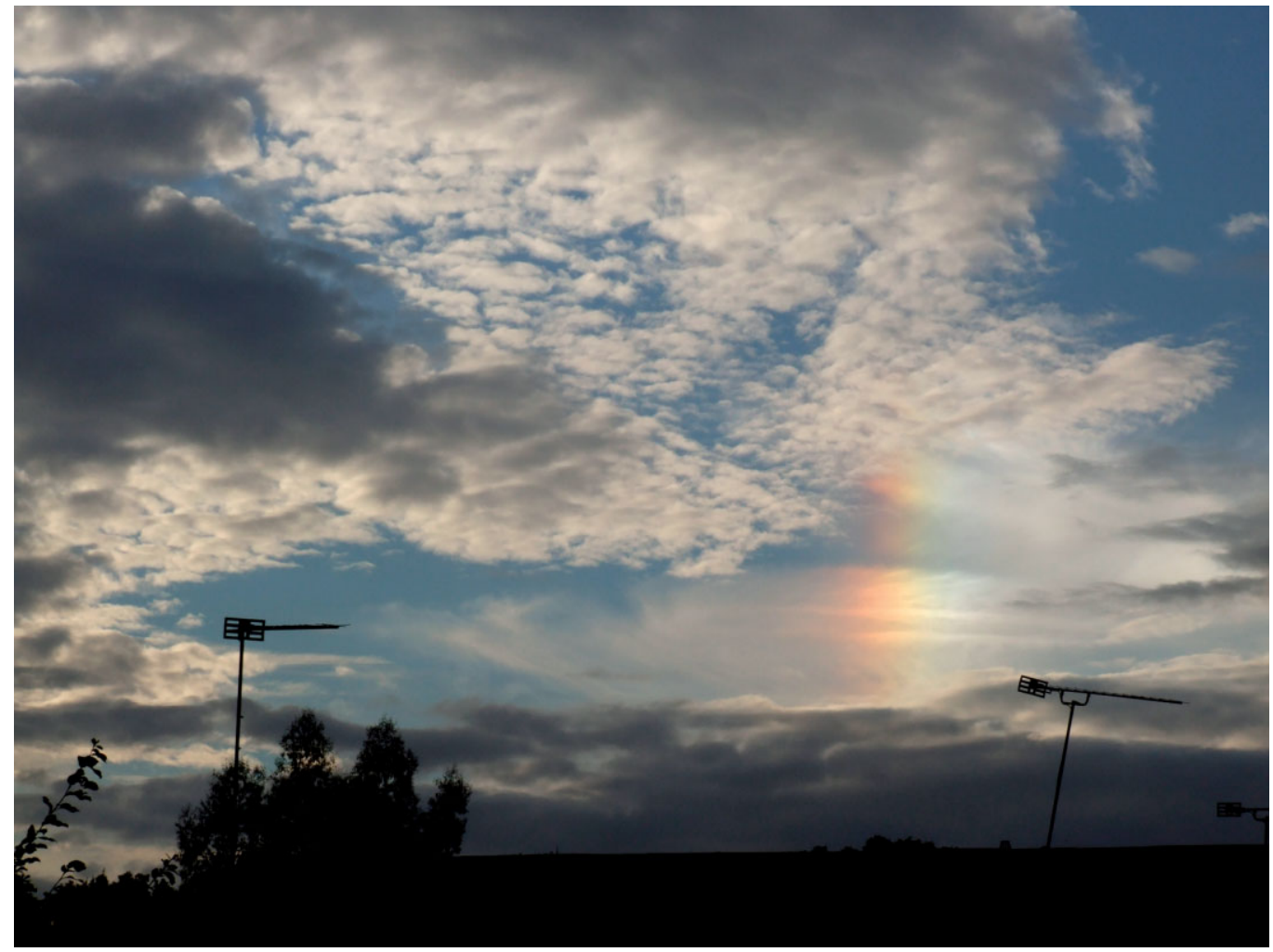

A parhelion (sundog) in a patch of cirrus, with altocumulus spreading from the west, at 1827 UTC on 13 August 2007, Wokingham, Berkshire. (๑ George D. Anderson.) 